\title{
The Republican Revival and Racial Politics
}

\author{
Derrick Bell $\nmid$ and Preeta Bansal $\dagger \dagger$
}

Harlem in the late 1930's remained locked in the hard times of the Great Depression. The earlier desperation had given way to a silent struggle for survival. During a quiet moment on a too-crowded block, an old, black man sat on his front stoop observing familiar activities of the community he served as respected sage. His wisdom, distilled during a long, hard life, dictated a pragmatism that bordered on cynicism.

He listened now to the earnest young street worker, an exile from the upper class, extolling the marvels of the Marxist millennium that would eventually replace the agony and travail of capitalist oppression. The old man had heard it all before, but he was patient as the young man harangued him about the brave, new, benefit-filled world that would come sooner if only black people would rise up and throw off their economic chains. When the young proselytizer finished, the black man said he had only one question.

"Ask me anything, Pop," the young radical urged. "I have the answers to all your people's problems."

"Well," asked the old man, "when you revolutionaries take power and change all the world over-will you still be white?"

For the old man in this story, as for all black Americans, experiencebased skepticism ${ }^{1}$ counsels caution whenever young radicals urge them to add the suspect symbol of communism to the stigma that color confers automatically and indelibly on African Americans. Blacks remain neither hostile to nor enthusiastic about the prospects of a Marxist world, but absolutely nothing that young militants might say can alter a truth made clear by a long history during which whites' determination to maintain a dominant position over blacks has been the unchanging constant of American life.

Skepticism is the necessary response for people of color who grapple with Frank Michelman's and Cass Sunstein's new republican concepts. And "grapple" is an apt word, because the writings of both scholars are dense with discussions of a character that only political philosophers can translate. Neither writer is an earnest, young proselytizer; neither is a

$\dagger$ Professor of Law, Harvard University.

t† Harvard Law School, Class of 1989.

1. See generally Minority Critiques of the Critical Legal Studies Movement, 22 HARv. C.R.-C.L. L. REv. 297 (1987) (legal reformers too often have dismissed cavalierly authentic experiences of black Americans). 
Marxist. Rather, they are two legal scholars whose works justify the respect and reputations they enjoy. And yet in reading their essays, black Americans may struggle to find reasons to allay their skepticism about the Michelman-Sunstein jurisprudential millennium, a world in which the positive aspects of classic republicanism and antifederalist thought would be resurrected, freed of the racism and elitism that marked their beginnings.

At first blush, the idea of reviving republicanism is appealing. Indeed, the concept of rediscovering the "disinherited" tradition in American thought ${ }^{2}$ is one that can never be completely repugnant to blacks struggling to carve out a space in the nation's political imagination. The republican revival's initial appeal fades quickly, however. The federalist-antifederalist debate that occurrèd two centuries ago was, after all, a debate from which blacks were excluded. Given that the antifederalist contingent was led by Thomas Jefferson, a southern plantation slaveholder who in many ways embodied the dichotomy between the founding fathers' ideals of equality and their unrelenting protection of human "property,"s how can it be conceivable that the disinherited antifederalists had so much more to offer to the struggles of black Americans than did the prevailing liberal heirs?

Deeper reflection quickly reinforces history-based doubts. Republicanism, through its faith in the existence of shared values and the possibility of a common good, assumes at base that a social consensus will emerge from "reasoned" deliberation by individuals who think "rationally" and who are capable of abstracting from their private experiences. ${ }^{4}$ For centu-

2. See Appleby, The American Heritage: The Heirs and the Disinherited, 74 J. AM. HisT. 198 (1987) (referring to antifederalist republican thought as the "disinherited" tradition in American constitutional history).

3. In his Notes on the State of Virginia, written in 1781, Jefferson justifies slavery by advancing his "suspicion only, that the blacks . . . are inferior to the whites in the endowments both of body and mind." T. Jefferson, Notes on the State of Virginia 138-39 (T. Abernathy ed. 1964). He urged that eventual emancipation must be followed by colonization "to such place as the circumstances of the time should render most proper." Id. at 132. Jefferson believed that if the legal barriers between the races were torn down, but no provision made for their separation, "convulsions" would ensue which would "probably never end but in the extermination of the one or the other race." Id. See generally J. Robinson, Slavery in the Structure of American Politics 1765-1820, at 89-90 (1971) (discussing in detail Jefferson's paradoxical views on race).

4. Indeed, Professor Michelman himself seems to draw heavily upon the Kantian conception of reason. See, e.g., Michelman, The Supreme Court, 1985 Term-Foreword: Traces of SelfGovernment, 100 Harv. L. REv. 4, 26-27 (1986) [hereinafter Foreword]. The Kantian notion of reason requires that there be public dialogue through which individuals may acquire self-cognition and that a common good ultimately will be reached through each individual's ability to abstract from her private experiences. "II]f a law is to be morally valid . . . the ground of obligation here must therefore be sought not in the nature of man nor in the circumstances of the world in which man is placed, but must be sought a priori solely in the concepts of pure reason . . . ." I. KANT, GrounDING FOR THE METAPHYSICs OF MORALS 2 (J. Ellington trans. 1981). The legal posture required by such pure normative reason is impartiality or passionless objectivity-stances that have been labelled distinctively white and distinctively male by several scholars. See, e.g., C. Gilligan, IN A DiffERENT Vorce (1982); C. MacKinnon, Desire and Power, in Feminism Unmodified 46 (1987); MacKinnon, Feminism, Marxism, Method and the State: Toward Feminist Jurisprudence, 8 SIGNS 635, 638 
ries in this country, however, blacks have served as the group whose experiences and private needs have been suppressed in order to promote the "common good" of whites. Indeed, the "shared values" in which the antifederalists laid faith included a historically constant and (for whites) a unifying belief in the inferior and subordinated position of black Americans. $^{6}$ The ability of the founding fathers to suppress the injustices of the black experience allowed them to arrive at a "common good" which tolerated (at best) and indeed sanctioned slavery. Such disregard for the actual experiences of minority groups in this country made it possible a century later for the Supreme Court to sanction racial segregation ${ }^{7}$ and for the Court's sole dissenter to decry the need for separate facilities because, as he boasted, the white race is the dominant race in this country "in prestige, in achievements, in education, in wealth and in power."

Just as both the federalists and antifederalists took as a base assumption the inherent justice and necessity of slavery, so also did policies of racial domination underlie society's transitions from slavery to segregation to desegregation. ${ }^{\circ}$ Despite the rhetoric of the current "equal opportunity" era, society retains racial domination as a consensus ideology by promising a nondiscriminatory present while simultaneously locking in the racial disadvantages of our blatantly racist past. ${ }^{10}$ Indeed, racial reforms in law

(1983); Sherry, Civic Virtue and the Feminine Voice in Constitutional Adjudication, 72 VA. L. REv. 543 (1986).

5. "Political democracy for the white man and racial discrimination for the black were often products of the same dynamics." C. Vann Woodward, The Strange Career of Jim Crow 7 (1955). Thus, "[t]he determination of the Negro's 'place' took shape gradually under the influence of economic and political conflicts among divided white people-conflicts that were eventually resolved in part at the expense of the Negro." Id. at 53.

6. See Crenshaw, Race, Reform, and Retrenchment: Transformation and Legitimation in Antidiscrimination Law, 101 HaRv. L. REv. 1331, 1371 (1988) (arguing that "stereotypes [about Blacks] serve a hegemonic function by perpetuating a mythology about both Blacks and whites even today, reinforcing an illusion of a white community that cuts across ethnic, gender, and class lines").

7. See Michelman, Foreword, supra note 4, at 31 ("[O]nly in sedulous abstraction from concrete experience could 'separate' have seemed 'equal." ").

8. Plessy v. Ferguson, 163 U.S. 537, 558 (1896) (Harlan, J., dissenting).

9. Even though individuals have become labelled as equals within American egalitarian ideology, hierarchy attaches no longer to defined social group roles, but to "somatic characteristics, physiognomy, colour of the skin, "blood." L. Dumont, Homo Hierarchicus: The Caste System and ITs IMPLICATIONS 263 (G. Weidenfeld trans. 1970). In fact:

It is obvious on the one hand that society did not completely cease to be society, as a hierarchized whole, on the day it willed itself to be simply a collection of individuals. In particular, the tendency to make hierarchical distinctions continued. . . . [R]acism fulfills an old function under a new form. It is as if it were representing in an egalitarian society a resurgence of what was differently and more directly and naturally expressed in a hierarchical society. . . . Societies of the past knew a hierarchy of status bringing with it privileges and disabilities, amongst others the total juridical disability of slavery. .. . The distinction between master and slave was succeeded by discrimination by White against Black. . . . [B]y suppressing [the masterslave distinction] the transformation of its racial attribute into racist substance was encouraged. Id. at 262-63.

10. See Crenshaw, supra note 6, at 1384 ("The narrow focus of racial exclusion-that is, the belief that racial exclusion is illegitimate only where the 'White Only' signs are explicit-coupled with strong assumptions about equal opportunity, makes it difficult to move the discussion of racism beyond the societal self-satisfaction engendered by the appearance of neutral norms and formal inclusion."); Freeman, Legitimizing Racial Discrimination Through Antidiscrimination Law: A Critical 
reflect less a late-blooming civic virtue than perceived changes in selfinterest by a society tardily willing to acknowledge the evils of slavery and segregation. ${ }^{13}$ How, then, can blacks feel anything but skepticism and cynicism when well-intentioned legal academics ask them to rely on a theory that extols the shared values of a deliberative democracy?

Republicanism's revival of the notion of a common good is not, however, the only frightening prospect that the theory presents to black Americans. Republicanism's exaltation of "active citizenship" contains the seeds of teleology and hierarchy in its implicit suggestion that some human roles-most notably, the role of the human being as citizen-are more true to the essence of humanity than are others. The virtuous citizen, however, can only be free to pursue his human essence through civic participation and through the life of the mind by having the luxury of material independence. " "Civic" societies in Athens and in early America effected this luxury in part by creating a subclass of humans who tended to the citizen's needs of the flesh and who were thereby excluded from the realm of public dialogue. ${ }^{13}$ In nineteenth- and early twentieth-century America, the citizen's need for material independence manifested itself simply in the de jure or de facto exclusion from political participation of those who were incapable of or unwilling to abstract from their private experiences and material context and who hence were regarded as unvirtuous. ${ }^{14}$ Indeed, regardless of the epoch, any attempt to define human essence or to posit a notion of the common good historically has resulted in hierarchy, exclusion, and alienation. ${ }^{15}$ Given the oppressive roots of republicanism, blacks cannot help but wonder how judicial standards, altered by Michelman's and Sunstein's updated principles of civic virtue

Review of Supreme Court Doctrine, 62 MINN. L. REv. 1049 (1978) (extension of formal rights to blacks ultimately has legitimized remaining racial inequality).

11. See Book Note, 101 Harv. L. Rev. 849, 850 (1988) (reviewing D. Bell, AND We ARE Nor SAVEd (1987)) ("[Bell's] chronicles serve as powerful, poetic reminders that . . . [w] wen blacks seek recognition of rights that do not also serve the interests of whites, the ambivalent foundations of whites' commitment to equality and individual rights become exposed.").

12. Historically, the granting of the franchise has been contingent on the freehold. Individuals not having the luxury of material independence have been viewed as "corrupt"; because such individuals are subject to the will of another for existence, republican theory has held them to be incapable of abstracted, normative reason. See J. Pocock, Civic Humanism and Its Role In Anglo-American Thought, in Politics, Language and Time: Essays on Political Thought and History 80, 87-89 (1973).

13. See ThE PoLitics of ARISTOTLE 108 (E. Barker trans. 1971) (the best state will not make slaves and mechanics citizens, since they are merely "necessary conditions" and not "integral parts" of the body politic). For a modern analysis of the division between the public realm of civic virtue and the private realm of affective and economic association, see Olsen, The Family and the Market: $A$ Study of Ideology and Legal Reform, 96 HARv. L. REv. 1497 (1983).

14. The restrictions on the franchise-based on economic status, race, and gender-were originally the means by which a republic ensured that its citizens were virtuous. See supra note 12.

15. See K. Polanyi, The Great Transformation 250 (3d ed. 1950) ("It is held, then, that there exists a Common Good, the obvious beacon light of policy, which is always simple to define and which every normal person can be made to see by means of rational argument. There is hence no excuse for not seeing it and in fact no explanation for the presence of people who do not see it except ignorance-which can be removed-stupidity and anti-social interest."). 
and deliberative democracy, can improve the legal status of the nation's disadvantaged in general and of black people in particular. What parts of the republican vision are capable of combatting and subduing the by-now familiar priorities for whites in racial policymaking, priorities that have preserved for whites their perpetual power?

Racial hypersensitivity? Perhaps. But American history has taught blacks that they must question how any newly-proposed scheme of political enlightenment is likely to affect them. They have learned by necessity to be wary of the rhetorical seductions of such theoretical schemes, having seen them time and again serve to exclude blacks from any significant share of improvements to the "common good." Much of the republican revival sounds pleasing to the intellectual ear, but, rather obviously, contemporary developments in the political law of race, as well as their historic antecedents, have failed to satisfy the demands of intellectual honesty or even logical consistency. ${ }^{16}$ The Court's decisions in McCleskey v. Kemp ${ }^{17}$ and Wygant v. Jackson Board of Education ${ }^{18}$ serve to remind us of this point.

Clearly Professors Sunstein and Michelman are deeply devoted to the American legal system-even as they lament its crushing historical defects. They put their considerable intellectual prowess to the task of surveying antifederalist thought, and from that survey they labor to piece together from myriad sources the innovative jurisprudential schemes they optimistically recommend. Yet black Americans are left wondering, not without sadness, whether those who, even a half-century later, share the old man's skepticism about the society's willingness to act out of virtue rather than self-interest, can ever understand, much less join, the Michelman-Sunstein commitment to making the world better by fashioning new principles out of elements traceable to the ideas and ideals of some of the framers. This is not too extravagant a concern or too unreasonable a skepticism. After all:

What is the mentality of a people that could continue for over 300

16. Twentieth-century notions of human personality have shed light on racism by repudiating the notion that the human mind is governed by exclusively rational or logical impulses. See J. Schumpeter, Capitalism, Socialism and Democracy 251 (1976) (absence of common good capable of being rationally derived "will introduce rifts on questions of principle which cannot be reconciled by rational argument because ultimate values-our conceptions of what life and society should be-are beyond the range of mere logic"); see also S. FREUD, The Ego and THE ID (J. Riviere trans., J. Strachey ed. 1960); G. LEBon, ThE CROWD (1960).

17. 481 U.S. 279 (1987). Rejecting evidence of a massive statistical study showing that blacks who murder whites in Georgia are 4.3 times more likely to receive death sentences than are defendants charged with killing blacks, the Supreme Court in McCleskey insisted on proof that the state had intended to discriminate against individual defendants. See generally Kennedy, McCleskey v. Kemp: Race, Capital Punishment, and the Supreme Court, 101 HaRv. L. REv. 1388 (1988).

18. 476 U.S. 267 (1986) In Wygant, the plurality held that the presence of prior employment discrimination did not provide constitutional justification for a government entity to use a program of race-conscious layoffs in its collective bargaining agreement. 
years to kidnap an estimated 50 million youth and young adults from Africa, transport them across the Atlantic with about half dying unable to withstand the inhumanity of the passage, and enslave them as animals? . . . What was the mind set of EuropeanAmericans as they encountered native Americans who were basically friendly to them, yet the European-Americans proceed to annihilate almost the entire race and/or force them onto reservations, stealing their land, and making themselves the heroes and the victims savage villains. What can be understood about the world view of a people who claim to be building a democracy with freedom and justice for all, and at the same time own slaves and deny others basic human rights? ?19 $^{2}$

Admittedly, Professors Michelman and Sunstein recognize the historically dubious roots of the doctrine they seek to rejuvenate. Nevertheless, Professor Michelman assures us that we need not fear republicanism's "sometime historical connection with an obnoxiously solidaristic social doctrine." 20 In order to tap what he views as the "visionary resources" of republican thought, Professor Michelman warns in stirring terms that American liberals should fear more "a constitutional jurisprudence that debases the community by slighting its self-transformative capacity and abets the community's self-betrayal through lapse of commitment to extension of membership to persons who, at many historical moments, could not count themselves heirs to traditions whose meanings did at those times involve the exclusion or subordination of just those persons."21

Surely, this is an elegant statement of the problem. But in the equally elegant discussions of government processes that follow, there seems to be little persuasive evidence that the reformation of republicanism will offer greater protection for the nation's "others" than now exists. Although Professors Michelman and Sunstein promote a vision of constitutional jurisprudence that is far from being racist and that in fact is more inclusive of black Americans than is current judicial wisdom, they seem to eliminate the elitist aspects of republican theory by clothing traditional liberal rights discourse in republican terminology.

In reaching for "republicanism's deeper constitutional implications"22 to demonstrate the inclusive aspects of republican theory, Professor Michelman urges us to recognize what republican theory can contribute to resolving the tension that runs throughout American constitutional thought-the tension between being a government of laws and a government of men, between law-rule and self-rule. He seeks to avoid being

19. L. Myers, Understanding an Afrocentric World View: Introduction to an OpTimal Psychology 8 (1988).

20. Michelman, Law's Republic, 97 YaLE L.J. 1493, 1496 (1988).

21. Id.

22. Id. at 1495 . 
caught between a rock and a hard place-between the Lochner judiciary's rejection on the basis of transcendental rights of the popular majority's attempts to legislate new notions of state obligation, and the Bowers Court's deference (and enslavement) to the legislature's enunciations of authoritarian law. ${ }^{23}$ Arguing that the Court in Bowers lapsed into "a politics of self-denial" in order to avoid replicating the Lochner Court's invalidation of "we the people's" attempts at self-government, he states that the modern judicial stance of process neutrality represents the Court's limited view of judicial role. This limited view seeks to effectuate self-rule by deferring to " 'the people's' self-enclosing tendency to assume their own moral completion as they now are."24

Professor Michelman argues that since so many of the "sources and channels of republican self-government and jurisgenerative politics"2s lie in nongovernmental settings, the judiciary must not look exclusively to the normative dialogue that occurs in legislatures in order to ascertain and honor "we the people's" will. Instead, the judiciary must recognize that various forms of public association-whether in the workplace or on the street-provide citizens with the "direct experience of self-revisionary, dialogic engagement"26 and that full participation requires that the various components of "citizenship" in these alternate spheres not be denied.

According to Michelman's republican constitutional theory, citizenship consists not merely in enfranchisement within the state, but also includes public respect for various features that are constitutive of self. When individuals' identities are disparaged or degraded publicly through law, these individuals are in some way denied "admission to full and effective participation in the various arenas of public life."27 By recognizing the need for individuals to be granted full participation in all spheres of "potentially transformative dialogue," ory thus avoids replicating the hierarchical and exclusive features of classical republican thought. Instead, Michelman argues that the republican revival allows the judiciary to "reach for inclusion of the other, of the hitherto excluded-which in practice means bringing to legal-doctrinal presence the absent voices of emergently self-conscious social groups." ${ }^{\prime 29}$

23. Professor Horwitz has applauded Professor Michelman's project, arguing that republican theory presents a serious attempt to justify the retreat from the Lochner era on substantively progressive grounds, and not merely on traditional judicial restraint grounds. Arguing that progressive retreat presents a new notion of the neutral state (as compared to the "nightwatchman" state of Lochner, or the paralyzed state and judicial apparatus of the modern era), he suggests that republican theory reintroduces the oft-neglected normative and constitutive character of law and thereby bridges the gap between naturalist and positivist conceptions of law. See Horwitz, Republicanism and Liberalism in American Constitutional Thought, 29 WM. \& MARY L. REv. 57 (1987).

24. Michelman, supra note 20 , at 1532.

25. Id. at 1531 .

26. Id.

27. Id. at 1533 .

28. Id. at 1531

29. Id. at 1529. 
Although the constitutional theory proposed by Professor Michelman promises to expand participation in the various spheres of civil society to traditionally disempowered and disenfranchised groups, it remains unclear how this theory can be substantively inclusive without lapsing into one person's liberal theory of prepolitical rights. Indeed, how can courts apply republican principles in such a way that they are vigilant and sensitive to the needs of blacks, homosexuals, and other minority groups with regularity and commitment, and at the same time give effect to the constantly political and revisionary activities of "we the people"? Claiming that it avoids the Lochner Court's evisceration of democratic self-rule through imposition of a notion of transcendental law, Professor Michelman's republicanism cannot do without defining which aspects of individuals' identities are more constitutive of self, or which groups are traditionally silenced and disempowered. Indeed, in order to be inclusive, the republican revival must establish certain baseline principles, such as defining which groups traditionally have been excluded from the channels of mainstream dialogue, that are not subject to continual revision by the outputs of democratic politics. And yet, once courts establish principles for resolving which groups or which identity traits are more worthy of respect in cases in which two or more interests come into conflict, the republican revival loses its immanent quality and instead reimposes law-like criteria by which courts judge the relative needs of various social groups.

Bowers is an easy case for demonstrating that Michelman's version of republicanism can be inclusive. In Bowers, there was a clearly excluded minority group that was disparaged by the popularly elected and supported legislature and that historically has been considered outside the mainstream of civil society. It is therefore simple to identify homosexuals as the "hitherto excluded" and to decry a law that would disparage their identity and diminish their citizenship status in the various spheres of civil society. In most modern cases, however, there is no defined "other" that can be clearly identified as such without recourse to instinctive notions based on personal context and experience. Indeed, most cases involve a controversy between two parties, both of whom may represent groups that are construed by some individuals as having been unduly silenced. In such cases, courts applying revived republican theory will have to determine which outcome will more likely deny an "excluded" group access to the various spheres in which dialogic, self-revisionary activity takes place. For example, in a rent control case, the court will be forced to decide whether a statute forcing landlords to lower rents in certain dwellings furthers or detracts from the possibility of critical, transformative dialogue among citizens. On the one hand, such a statute would grant less wealthy individuals an essential prerequisite to full participation in civic society-a home 
through which they can affirm their identity and form an attachment. ${ }^{30}$ On the other hand, such a statute would deny a landlord the full enjoyment of her property and make insecure the material base that grants her the "independence" allowing her to participate fully and virtuously in civic life. ${ }^{31}$ Rather than providing judges with a principled basis upon which to decide controversies, then, the republican revival merely reproduces the tension that runs throughout American constitutionalism. In attempting to make law more immanent and more responsive to the demands of popular self-rule, republicanism cannot escape the need for transcendence, consistent rules, and hence some measure of undemocratic and arbitrary output. ${ }^{32}$

30. Professor Radin has argued that personal property is constitutive of identity whenever individuals form personal attachments to it or whenever the property has become identified with a person, with her self-constitution in the context of her environment. In such cases, personal property cannot be taken away and replaced with money or other things without harm to an individual's personhood, to her identity and existence. See Radin, Property and Personhood, 34 Stan. L. Rev. 957 (1982). Although a tenant's apartment is not "property" in the legal sense, it nevertheless may be the source of great personal attachment. Under republicanism, therefore, a tenant's home necessarily would be respected as a source of identity that could not be disparaged or denied without concomitant harm to the tenant's full "citizenship." For an analysis of other examples of nonfungible noncommodities that are integral to an individual's personhood, see generally Radin, Market-Inalienability, $100 \mathrm{HARV}$. L. REv. 1849 (1987). Clearly, multiplying the number of recognized nonfungible noncommodities or the number of aspects constitutive of individuals" "personhood" could complicate the republican task greatly.

A rent control statute would promote the republican vision by providing a means for extending the material independence necessary for citizenship to impoverished tenants. Critical to republican theory and active citizenship throughout history has been the recognized need for individuals to be allowed certain material prerequisites, such as a home and the means for subsistence, that grant them the independence necessary for virtue. Although republics historically have met this requirement of material independence by excluding from the franchise any individuals not having possession of a freehold, see supra note 12, "revived" republicanism proposes a more inclusory strategy in which periodic redistributions of wealth ensure that individuals are guaranteed the material prerequisites of independence. See Michelman, Possession v. Distribution in the Constitutional Idea of Property, 72 Iowa L. REv. 1319 (1987). Of course, this strategy replicates the central dilemma underlying constitutionalism; it cannot answer the question of how periodic, collective reimaginations and redistributions of wealth are to take place without upsetting the property "rights" of those who depend upon them for material independence. See infra note 31 .

31. The republican need for securing material independence to ensure virtuous citizenship thwarts the republican attempt to dismantle legal rights as artificial constraints on political freedom. Indeed, republicanism is forced to choose between its dual necessities-granting material independence and the means for citizenship to all individuals (e.g., making apartments more accessible to tenants and granting other forms of economic benefit) on the one hand, and securing material independence for existing citizens (e.g., securing a steady stream of adequate rents) on the other. Therefore, in its attempt to escape "law-likeness" and property "rights" by making existing distributions of property more inclusive through collective revision, republicanism cannot deny the need for some established "minimum" property right that remains outside the realm of political revision. Cf. F. HAYEK, Taxation and Redistribution, in The ConstituTION OF LIBERTY 306 (1960) (doubting that progressive tax schedule, despite its law-like formality, could ever be removed from realm of politics and placed into realm of law).

This is not to deny that a similar tension besets the liberal vision. On the one hand, liberals seek the restraint on politics and the "law-likeness" that a transcendental notion of property rights symbolizes, yet liberals also need to accept the necessity of modifying (periodically) property entitlements in order to achieve their vision of equality. See J. Nedelsky, Property vs. Democracy: The OrIgins and Structure of THE UNITEd States Constitution (forthcoming 1988). Pointing out the property rights tension in republican thought does demonstrate, however, that republicanism cannot escape the same dilemmas that beset liberal constitutional thought.

32. In its repudiation of rights and legal rules as abstracted and alienated forms of authority, 
In seeking the republican revival, however, Professor Michelman himself seems to acknowledge the need for something more than pristine logic enhanced by reconsidered history. So, after a lengthy excursion through the complexities of republican theory's contribution to "self-rule as lawrule," "jurisgenerative politics," and innumerable discussions of modern pluralist political science, he concedes that republican theory's main value lies in its aspirational content. ${ }^{33}$ Recognizing that judicial invalidations of majoritarian politics result in legal rules that, although inclusive, are contrary to actual popular democracy, Professor Michelman nevertheless asserts that even a countermajoritarian manifestation of the republican revival can contribute greatly to political freedom and self-government. Through dialogue and critical self-reflection, judicial panels applying republican principles can replicate the normative conversations occurring on the streets and in town councils, thereby enabling the judiciary to become "a bastion of (its own) self-government" that assumes as one of its "ascribed functions the modeling of active self-government that citizens find practically beyond reach."34 Even while invalidating the outputs of popular sovereignty, the judiciary therefore can, according to Michelman, produce "law's republic," which creates the freedom for individuals to assume full participation in alternative spheres of social life and public dialogue.

According to Michelman, law's republic recognizes the voices from the

revived republicanism draws significantly from the Marxist critique of rights. See K. MARx, On the Jewish Question, in EARLY WRITINGs 211 (R. Livingstone \& G. Benton trans. 1975). Such a repudiation also mirrors the mode of analysis used by legal scholars associated with Critical Legal Studies. See, e.g., Gabel, The Phenomenology of Rights-Consciousness and the Pact of the Withdrawn Selves, 62 TEX. L. Rev. 1563 (1984) (legal rights reproduce hierarchy and "legalize" alienation); Tushnet, An Essay on Rights, 62 TEX. L. Rev. 1363 (1984) (rights are indeterminate and cooptive abstractions).

33. In fact, in rhetorically questioning the possibility of jurisgenerative politics, Professor Michelman argues that republican constitutionalism may be possible "either not at all (that is, its possibility depends on false or incredible assumptions about social facts), or only on conditions of social ordering or control that are too onerous or repellent to accept. Such a demonstration I would regard as neither a refutation of this essay nor a sign of its failure; if republican constitutionalism isn't possible for us then it isn't, and we may as well know plainly on what rock our ship has for some time been foundering." Michelman, supra note 20, at 1506.

His project thus resembles that of Karl Polanyi, who observed that "the inevitable result of the liberal philosophy, which claims that power and compulsion are evil, [is] that freedom demands their absence from a human community. No such thing is possible; in a complex society this becomes apparent." K. PolanYI, supra note 15, at 257. Recognizing the futility of seeking freedom from actual or alienated authority in a complex world, therefore, Polanyi in the end clings to the same faith that has motivated the struggle of black Americans for centuries and that ultimately captures Professor Michelman's republicanism.

[Man] resigns himself, in our time, to the reality of society which means the end of that freedom. But, again, life springs from ultimate resignation. Uncomplaining acceptance of the reality of society gives man indomitable courage and strength to remove all removable injustice and unfreedom. As long as he is true to his task of creating more abundant freedom for all, he need not fear that either power or planning will turn against him and destroy the freedom he is building by their instrumentality. This is the meaning of freedom in a complex society; it gives us all the certainty that we need.

Id. at 258B.

34. See Michelman, Foreword, supra note 4, at 74. 
margin and seeks to include them in the conversation at the center. It seeks to make real the ideals of political freedom not by responding to "talismanic invocation of [popular] authority" but rather by fashioning democratic and inclusive rules out of the "cognizable normative universe" in which justice to individual parties is as valued as is the notion of popular sovereignty. ${ }^{35}$ Although Michelman recognizes that this brand of judicial self-government runs in tension with actual democracy, still, "[t]hat difficulty, too, must yield (if at all) to a pragmatic consideration: Actual democracy is not all there is to political freedom, and Hardwick is before us, appealing to law's republic."36

Unable to find a principled basis for resolving disputes under the broad aims of republican theory, Professor Michelman thus is constrained in the end to rely on faith in the judiciary's ability to hear voices from the margin. Yet bringing content to the inclusive, democratic promises of American constitutionalism -indeed, to those elements of political freedom that popular sovereignty cannot be relied upon to produce-requires not so much intellectual understanding as an abiding faith able to weather political perfidy and judicial betrayal. Relying on that faith, blacks for decades have sought the ideal of equality even while acknowledging the accuracy of academics who in recent years have proclaimed the indeterminacy of that ideal. Recognizing that constitutional rights have never translated into literal mandate for white leaders responding to black demands for equality, blacks nevertheless have clung to the Constitution as an embodiment of the ideals of freedom and equality for all:

[I]t is also true that blacks always believed in rights in some larger, mythological sense-as a pantheon of possibility. It is in this sense that blacks believed in rights so much and so hard that we gave them life where there was none before; held onto them, put the hope of them into our wombs, mothered them, not the notion of them; we nurtured rights and gave rights life. And this was not the dry process of reification, from which life is drained and reality fades as the cement of conceptual determinism hardens round, but its opposite. This was the story of Phoenix; the parthenogenesis of unfertilized hope. $^{37}$

In appealing to "law's republic," Professor Michelman relies upon this kind of faith in normative ideals and political struggle that blacks have pursued in demonstrating the paradoxical opposition between "their situa-

35. Id. at 76 .

36. Michelman, supra note 20 , at 1537 ; see also Michelman, Foreword, supra note 4 , at 73 ("[F]reedom's connection to self-government does not lie only, or ultimately, in the protective function of popular sovereignty, invaluable though that function is.").

37. Williams, Alchemical Notes: Reconstructing Ideals from Deconstructed Rights, in A LEss Than Perfect Union: Alternative Perspectives on The United States Constitution 56 (J. Lobel ed. 1988). 
tion and its relation to our (and increasingly their) Constitution." ${ }^{\text {"38 }}$ Relying on the judiciary's ability to hear voices from the margin and to fashion an inclusory strategy granting citizens full access to the arenas of social life, he asks rhetorically, "does anyone doubt the primary and crucial role in this instance of the emergent social presence and self-emancipatory activity of Black Americans . . . [that has] left its clear imprint on constitutional law both within and beyond the topical area of race[]?"39 In so asking, Michelman demonstrates that he, like generations of black Americans, recognizes the defects in our democracy and yet remains motivated to sift through the ashes of our political and jurisprudential past for remnants of what might have been and, in his view, what might yet be. This is what the Michelmans and Sunsteins in our midst know, and who can say that their vision is flawed beyond all feasibility? Certainly not the old man of the story, nor those black people who recognize that their survival depends on making real the ideals that are so frequently espoused in this society and so little observed. Skepticism about the republican ideal would stem less from disbelief than from concern that too often coalitions forged in the name of improved government are wrought through compromises that sacrifice participation by blacks. ${ }^{40}$ That is the inescapable-and seemingly unchangeable-pattern of this country's political and judicial functioning.

Having Professors Michelman and Sunstein join blacks in the quest to make real the ideals and aspirations of American democracy through abiding faith in the judiciary is not a negligible contribution on their part. By gross definition, they both are members of the oppressor class. They are, however, obviously aware of the oppression their society imposes by color and class-based fiat. Indeed, the essays are their offering to the struggle, exercises in scholarship that are reflections of their concern and, perhaps, manifestations of their faith.

Inadequate? Probably, given the logic-defying barriers of power-based precedent lurking just behind the dense smokescreen of race. But the oppressed will not triumph over these barriers through faith alone. And those slender reeds that are accepted as "black progress" cannot emerge without the nurture of some whites who realize that the oppression of blacks does not oppress blacks alone, but, indeed, that it denies all of humanity the full emancipatory potential of critical, dialogic self-rule. Thus, while the current interest in civic republicanism may be a passing fashion for those with the luxury to revel in the life of the mind, the skepticism that is a necessary defense for the perpetually disadvantaged should not blind minorities to the possibility that faith in the intellectual solution

\footnotetext{
38. Michelman, supra note 20, at 1530.

39. Id.

40. D. Bell, Race, Racism and American Law $\S 1.9$ (2d ed. 1980) (The Principle of Involuntary Sacrifice).
} 
may be as deserving of recognition as faith that our humanity will not always be subordinated because we are not white. 
